\title{
Necessity of Customer Loyalty Formation and its Peculiarities in the Telecommunication Services
}

\author{
Iveta Linina \\ Turiba University \\ Riga, Latvia \\ iveta.linina@turiba.lv
}

\author{
Velga Vevere \\ EKA University of Applied Sciences \\ Riga, Latvia \\ velga.vevere@gmail.com
}

\author{
Rosita Zvirgzdina \\ Turiba University \\ Riga, Latvia \\ Rosita@turiba.lv
}

\begin{abstract}
Everyday life is unimaginable without telecommunication services; they are the significant players in the national economy. All business activities, including the ones of telecommunication services, are directed towards the satisfaction of customers' needs and wants, and hence towards the profit earning. This process, in its turn, entails the formation of different company/customer relations, where both parties want to gain something out of these relations. The company strives, first of all, to increase the turnover and profit, while the customer wants to receive the desired services, information and the proper attitude. These customer gains can be basis of the loyalty formation, that is very important for the company, because the process of attracting new consumers always involves spending money, time and energy. The goal of this work is to explore the loyalty formation process and its peculiarities in the telecommunication services. Based on the results of the study, it was found that the experts rated the offer of corporate loyalty programs at the lowest, then followed the service offer and the price, but slightly higher the service quality. The experts assigned the highest rating to the prestige of the service. Based on the low assessment of the experts in the telecommunication industry of the loyalty program offer, the authors propose the conceptual consumer loyalty model for the practical use.
\end{abstract}

Keywords-Consumer satisfaction, loyalty, relationship management, telecommunication services.

\section{INTRODUCTION}

The importance of the behavioral economy nowadays is an indisputable concept, which is confirmed by the Nobel Prize awarded economist Richard Thaler. Focus on consumers, the research and satisfaction of their needs is geared towards the use of consumer relationship management within the company. The consumer satisfaction and its management have become the foundation of the company's competitiveness and the integral part of the business. On the basis of the research carried out, the cost of attracting a new consumer is 5-10 times higher than selling to an existing consumer, and the existing consumer spends $67 \%$ more money than new consumers [1]. Therefore, the company's mission is to develop a system that would ensure the consumer's desire to re-purchase and stay in touch. By gaining an understanding of the factors that shape consumer loyalty and using them skilfully, the company earns the greater customer trust and significantly increases its competitiveness. Properly researched and understood the consumer satisfaction factors form a competitive advantage of the company. The telecommunications companies in Latvia do not have the sufficient understanding of the customer relation management, especially the benefits of it.

The current study focuses on the factors affecting the consumer loyalty in the telecommunications sector, albeit the consumer loyalty formation process can never been finished, it is a business improvement mechanism. There are different consumer management systems, however, the unifying criterion for all of them is a satisfied, loyal customer that would ensure the competitiveness in the long run.

The goal of this work is to find out the main factors of consumer loyalty in the telecommunication sector and to define the peculiarities of this process, which would allow companies to improve their performance and ensure their competitiveness.

To achieve the goal, the following tasks were set:

1. To analyze the theoretical factors of consumer loyalty formation.

2. To describe the telecommunications sector and its development in Latvia.

3. To determine the main factors and peculiarities of consumer loyalty formation in the telecommunication industry with an expert interviews.

In order to determine the consumer loyalty trends in Latvia and to put forward the proposals for improvement of consumer loyalty formation, the experts have been interviewed during the research and the following restrictions have been identified: the problem is mainly studied from the methodological aspects. The research period: January 1, 2019 - March 1, 2019.

The following research methods have been used: the logical-constructive method - comparison of theoretical material and empirical results; the graphical method - for

Print ISSN 1691-5402

Online ISSN 2256-070X

http://dx.doi.org/10.17770/etr2019vol1.4124

(C) 2019Iveta Linina, Velga Vevere, Rosita Zvirgzdina. Published by Rezekne Academy of Technologies.

This is an open access article under the Creative Commons Attribution 4.0 International License. 
the visualization and analysis of the visual information, as well as the expert interviews. The methodological basis of the research consists of the works and publications by R. Brandt, C. Homburg, I. Howard, and others, which provide an insight into the factors and processes of the consumer loyalty formation.

\section{MATERIALS AND METHODS}

Consumer satisfaction is one of the necessary conditions for building the long-term and beneficial business relationships with consumers, but loyalty is one of the most important end results. Loyalty is the result of the consumer's perception of the supply (product, service, brand, etc.), which has led to positive attitudes (cognition, trust and emotional) and positive action regarding the offer (repeated purchases, additional purchases, high consumption intensity, etc.) [2]. The process of attracting new customers to business is much more expensive than keeping the existing ones, since the regular consumers spend more, but the company costs less [3]. The researchers [4] have found that only about $15-20 \%$ of the costs necessary to attract new consumers are sufficient to maintain the loyal consumers. Based on empirical studies, the other authors [5] claim that costs of attracting the new consumers is $5-7$ times higher than keeping the existing ones.

Most empirical studies show that there is a close relationship between consumer satisfaction and loyalty [6] - [7]. There is no single point of view on this relationship. Some researchers believe that the type of relationship may depend on the market situation, the characteristics of the offer, the peculiarities of the target audience. In markets with intense competition, it has been shown, the relationship between consumer satisfaction and loyalty is characterized by a progressive graphical form, but in markets with a relatively low intensity of competition it is characterized by a digressive graphical form [8] [9]. The empirical studies have demonstrated that there is a relationship between the consumer satisfaction and loyalty, which can be graphically represented by a S-shape, because only when the consumer is seduced, the loyalty rises very fast; when he is in the indifference zone, the loyalty is stable, but the location in the frustration area leads to the loss of loyalty [10]. Other researchers, however, have found occasionally the illogical situations when there are the satisfied, but ill-fated consumers and the unhappy and loyal consumers [11] - [12].

The researchers in the service sector [13] have argued that the customer loyalty is influenced by the service quality, the emotional satisfaction and the corporate image / reputation. The authors have come to this conclusion after a survey of 600 respondents - the service company clients in Greece. Other authors [14] - [15] - [16] demonstrated that the quality of the product and the image of the company directly or indirectly affect the consumer loyalty in other sectors. Still, the authors of the current article disagree with the opinion of the above-mentioned authors that the emotional satisfaction is considered to be a factor influencing loyalty, because in essence emotion is a component of the loyalty attitude dimension, and the satisfaction is the result of the consumption.

In Norway, a special Consumer Satisfaction and Loyalty Measurement (EPSI) rating was developed based on the relevant model (see Figure 1). The model shows that the values perceived by the consumer includes: the image of the company, the consumer's expected supply values, the actual quality of the product and the quality of service. These perceived values determine the satisfaction and the resulting consumer loyalty [17]. Firstly, the model assumes that all factors affecting satisfaction can also affect directly, i.e. without the consumer's perception. In our opinion, this can be true for the consumers with a high degree of loyalty, when the pre-purchase selection is practically automatic. Secondly, the image of the company and the quality of service can directly affect loyalty even without a stage of satisfaction. Obviously, this relationship also depends on the level of loyalty of the consumer, that is, the higher the level loyalty - the higher the level of satisfaction.

Perhaps the study of loyalty attitudes and dimensions of action would have led to other conclusions about the direct impact of loyalty on the progress. The authors of the current research also disagree with the thesis that expectations of the consumer offer is related to values that affect the satisfaction. Before the satisfaction / dissatisfaction is determined, the actual and the expected offers are being compared, and this largely psychological process is linked to the perception of the consumer. Meanwhile, the monetary value is not included in the model unreasonably (see Figure 1).

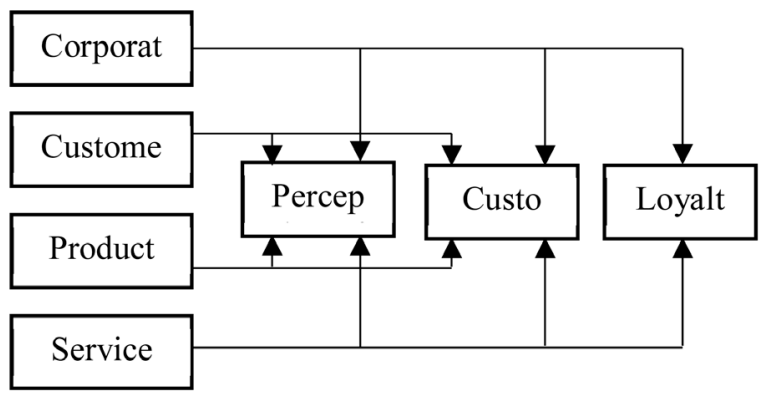

Fig. 1. Loyalty model according to EPSI rating (Source: Authors')

Based on the analysis of the advantages and disadvantages of loyalty models discussed above, the authors recommend to introduce the conceptual consumer loyalty model for the practical use (see Figure 2). This model is versatile in its nature, but can be used in practice, taking into account the peculiarities of the industry / product / brand.

It might be concluded, that the consumer loyalty processes include the following logically related elements:

- Factors influencing loyalty (values);

- Perception of consumer values;

- Peculiarities of the target audience;

- Consumer satisfaction;

- Dimensions of consumer loyalty. 


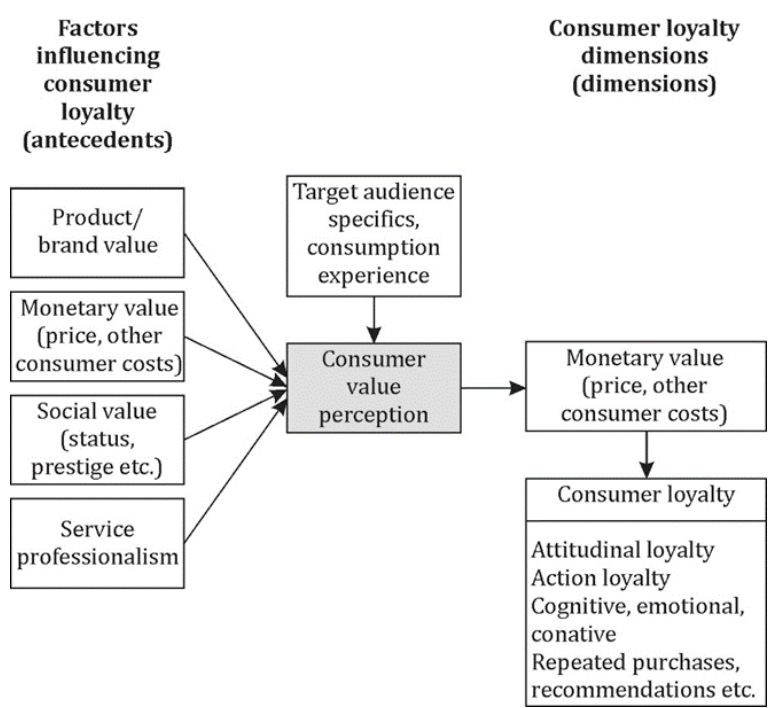

Fig. 2. Conceptual model of consumer loyalty formation (Source: Authors')

The loyal consumers have the following characteristics: they buy more and remain faithful for longer, they are less sensitive to the price increase, and they recommend other consumers to buy and consume / use a particular product / a brand. It is beneficial to the company, because:

- Communication from mouth to mouth costs nothing;

- Recommendations contain specific information based on the consumption / use experience.

- Communication comes from friends and / or acquaintances one can trust.

In essence, the consumer loyalty increases the value and competitiveness of a business because:

- It requires the lower costs for attracting consumers;

- Stable consumer database;

- Increase the product / brand prices within certain limits;

- Promote product sales and profits;

- Promotes a positive image and reputation of the company.

Of course, the peculiarities of the loyal consumer behavior and the benefits of the company depend on the level of loyalty. Therefore, it is necessary to study in more detail the loyalty process in a specific sector of the economy.

\section{RESULTS AND DISCUSSIONS}

Analyzing studies by various authors, it can be concluded that there are differences in understanding of the satisfaction process in three sectors of the economy: in the consumer goods sector [18] - [19], in the industrial goods sector [20], and in the service sector [21] - [22]. The object of the research of the current study - the telecommunications sector - is included in the service sector.

At the moment, there is a huge increase in the volume of information transmission in the world and the corresponding development of the telecommunications networks. Today's life is hard to imagine without the modern telecommunication means. The development of mobile telecommunication, cable television and fiber optic transmission systems, the strengthening of radio and television broadcasting stations create the increased demand for the services in question (see Figure 3 ).

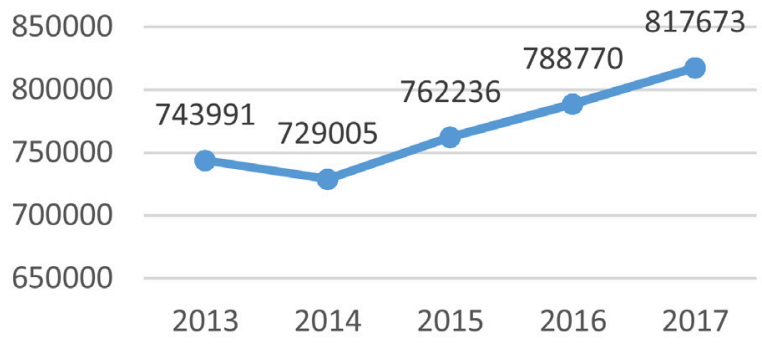

Fig. 3. Telecommunications industry turnover in Latvia in 2013 2017 (Thousands of EUR)

(Source: Authors' according to www.csb.gov.lv)

Despite the current growth rates in the telecommunications industry, the internal competition within the industry is increasing. On this basis, companies in the telecommunications sector need a tool that would ensure the competitiveness and create the continuous business relationships with the consumers.

Expert methods are increasingly used in the assessment and forecasting of socio-economic processes. The expert survey is mainly used for diagnosing and forecasting industry problems and analyzing and solving the research problem [23]. The expert is a qualified specialist in the field who expresses his / her opinion, for example, in the evaluation of the activity. In addition, the expert can evaluate different (significant and insignificant) factors, goals, better ways to achieve them, performance results, etc. Thus, the authors of the article have chosen the method of expert survey for the research, which is considered one of the most suitable methods for assessing loyalty in the telecommunications sector. Unlike statistical methods, the experts take into account a number of non-analyzed factors due to their experience and knowledge of the situation in the telecommunications sector.

In the implementation of the expert survey method, the authors followed four stages.

1. Preparation of the expert survey. The following tasks were solved at this stage:

- the problem to be investigated was formulated and the purpose of the expertise was clarified - to evaluate loyalty processes in the telecommunications sector in Latvia;

- based on the purpose of the expertise as well as the specificity of its object, a specific expert method was selected - a survey with structured questions;

- A questionnaire was developed.

2. Selection of experts and composition of the expert group. At this stage, the numerical composition of the expert group was determined, the expertise of the expert group was analyzed, and the experts were provided with the necessary information. After consulting with several experts and taking into account the expertise of 
the experts in this field, the authors identified a group of nine experts. When selecting experts, the authors of the thesis were guided by the experience and knowledge of the specialists and by the ability to understand the whole process. Potential experts responded to questions about loyalty factors and the specificities of the telecom sector and, on the basis of this scale, assessed their level of competence in each issue, scoring the maximum in the area in which the specialist is best. The authors then compared the individual evaluations of each specialist with the average self-assessment of all potential experts on all issues. The level of competence of a numerically potential expert was assessed by the formula [24]. As a result a group of experts was formed to include the selected experts, altogether 12 persons, that met all preconditions.

3. Characteristics of the expert survey. The expert survey was conducted in January-February 2019. Based on the objectives of the expertise and taking into account the peculiarities of the expert group, the authors of the thesis chose the following expert survey characteristics:

- An individual survey, where experts participate independently from each other;

- Extramural survey, where experts provide individual responses without the direct assistance of the organizers of the expertise;

- A closed-type survey when each expert is not informed about the answers of other experts;

- Closed-ended questions, where for each evaluation (according to Likert's scale in a 10-point system, 1 very low, and 10 very high), a certain scale has been given above, and the expert only has to choose one of the quantitative assessments.

4. Statistical methods of processing and analysis of expert assessments. If expert evaluations are given in scores, a broad statistical analysis can be performed. Using the SPSS computer program, the authors calculated the following indicators:

- the amount of expert assessment;

- Average Arithmetic Expert Assessment (X);

- Median (Me);

- Mode (Mo);

- Variation amplitude;

- Standard deviation;

- Coefficient of variation [25].

Based on the factors influencing loyalty, five blocks of questions were created - service and service quality, service price, service provider's business performance, service prestige and service provider program offerings. The results are depicted in the Table 1.
TABLE 1 EVALUATION OF THE LOYALTY FORMATION FACTORS BY THE EXPERTS IN THE TELECOMMUNICATIONS (SOURCE: Authors')

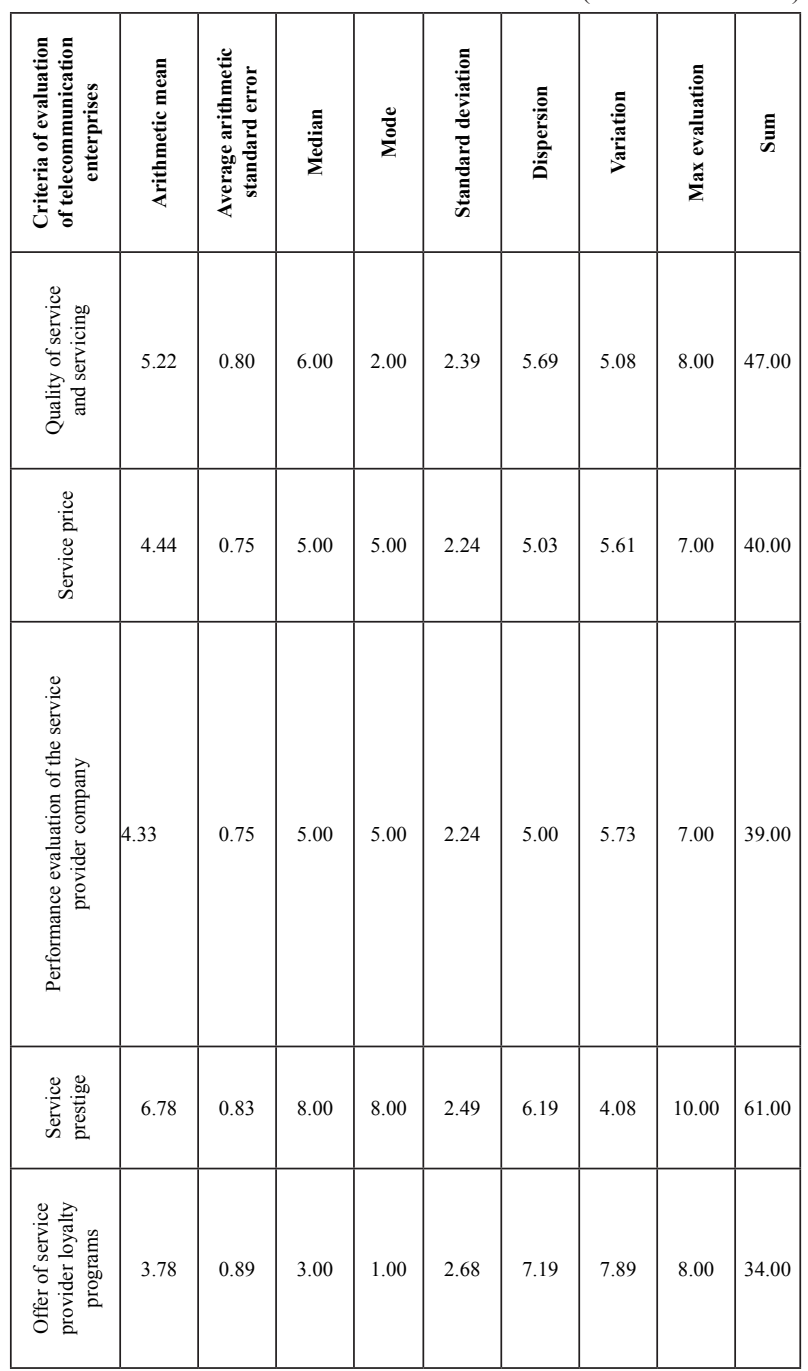

In order to assess the situation in the telecommunication sector, the authors of the article conducted analysis of the results of the expert survey (see Table 1). As it can be seen, the lowest rating $\left(\mathrm{X}^{-}=3.78 ; \mathrm{Me}=3.0 ; \mathrm{Mo}=1.00\right)$ was assigned to the criterion "service provider loyalty program offer". Mostly, it was due to the lack of loyalty programs or an ineffective operation. This is a significant score, as consumer loyalty is a very important indicator of competition. It is also apparent from the data on the company's own performance $\left(\mathrm{X}^{-}=4.33 ; \mathrm{Me}=5,00 ; \mathrm{Mo}=\right.$ $5.00)$ and service prices $\left(\mathrm{X}^{-}=4.44 ; \mathrm{Me}=5 ; 00 ; \mathrm{Mo}=5.00\right)$. The experts pointed out that the cause of the termination of the service is mostly related to the telecommunications companies themselves. This fact points to the unfair behavior by the company and the restriction of consumer choice. According to the information provided by the telecommunications industry, the business services are used by the consumers over a long time period, but there are signs of the forced loyalty, according to the experts. In general, it should be noted that the indicators have rather low ratings and a large amount of variation (see Table 1). In addition, there is a pronounced trend - the lower the average arithmetic (X,), the greater the variation volume. This means that different companies have different valuations for different aspects. 


\section{CONCLUSIONS AND RECOMMENDATIONS}

1. Consumer loyalty is the result of the perception of supply by consumers, which has led to positive attitudes and favorable behavior for the company.

2. The consequences of consumer loyalty are diverse, but its main aim is to facilitate the repeated purchases. Other signs of loyalty - low sensitivity to prices and positive "mouth-to-mouth" communication are less typical because they do not relate to retail valuation as a whole but rather to attitude to the individual products / brands.

3. Based on the results of the study, it was found that the experts rated the offer of corporate loyalty programs at the lowest (3.78), then followed the service offer (4.33) and the price (4.44), but slightly higher the service quality (5.22). The experts assigned the highest rating to the prestige of the service (6.78). Evaluations, in general, are very low, but do not reveal the real reasons for the assessment that goes beyond the present study.

4. Based on the low assessment of the experts in the telecommunication industry of the loyalty program offer, the authors propose the conceptual consumer loyalty model for the practical use (see Figure 2). This model is versatile in nature, but should be used by taking into account the peculiarities of the industry / product / brand. From the point of view of the authors, the loyalty model (see Figure 2) should be the basis of the relationship with the consumer formation and management process.

5. In the telecommunications sector, the consumer loyalty should be addressed more specifically, since by now there has been a little research.

\section{REFERENCES}

[1] J.-L. Anderson, L.-D. Jolly and A.-E. Fairhurst, "Customer relationchip management in retailing: A content analysis of retail trade journals" in Journal of Retailing and consummer services, vol. 14 , no 6,2007 . “

[2] I. Linina and R. Zvirgzdina, "The Consumer Loyality Formation Process and its Particularities in the Retail Sector" in Journal of Business Economics and Management, Vilnius [Online] Available: $\quad$ http://bm.vgtu.lt/index.php/verslas/2016/paper/ viewFile/23/23 [Accessed February 14, 2019] http://dx.doi. org $/ 10.3846 / \mathrm{bm} .2016$

[3] H. Karjaluoto, C. Jayawardhenda, M. Leppaniemi, and M., Pihestrom, "How value and trust influence loyalty in wireless telecommunications industry," Telecommunications Policy, 2012, pp. 636-649.

[4] W. Mueller, H.-J. Riesenbeck, "Wie aus zerbriedenen Kunden auch anhaengliche Kunden Werden," Harvard Manager, bind 3(13), 1991.
[5] A. Hermann and F. Huber, "Kundenloyalitat des Erfolgsdeterminante im Marketing," Journal fur Betriebswirtschaft, bind 47(1), 1997, s. 4-25.

[6] V. Mittal, W.-A. Kamakura, "Satisfaction, Repurchase, intend and Depurchase Behavior: Investigating the Moderating Effect on Customer Characteristics," Journal of Marketing Research, vol. 38(1), 2001, pp. 131-142.

[7] T. Jones and W. Sasser, "Why Satisfied Customer Defect," Harvard Business Reviev, vol. 73(6), 1995, pp. 88-99.

[8] Ibid.

[9] C. Homburg and A. Giering, "Kundenzufriedenheit: Ein Garant fur Kundenloyalitat?” Absatzwirtschaft, Nr. 1-2, 2000, s.82-91.

[10]K. Matzler and H. Pechlaner, Management von Kundenzufriedenheit: 10 Trugschlusse. Vom Alten zum neuen Tourismus, Beitrage aus Forschung und Prahis, Innsbruck, Studia Verlag, 2001.

[11]D. Finkelmann andA. Goland, "Information Strategy," The Executives Journal, vol. 6(4), 1990, pp. 5-10.

[12] M. Cano, S. Drummond, C. Miller, and S. Barclay, "Learning From others: Benchmarking in diverse tourism enterprises," Total quality Management, vol.12 (7,8), 2001, pp. 974- 980.

[13]N. Giovanis, D. Zondiros, and P. Tomaras, P. (2014). "The antecedents of customer loyality for broad band services: The roll of service quality emotional satistaction and corporate image," Procedia Social and Behavioral Sciences, vol. 148, 2014, pp. 236-244.

[14]T.-S. Dager, J.-C. Sweency, "The effect of service evalutions on behavioral intentions and quality of life," Journal of Service Research, vol. 9, 2006, pp. 3-18.

[15]P. Shukla, P, "Effects of perceived sacrifice quality value and satisfaction on behavioral intentions in the service environment," Services Marketing Quartely, vol. 31, 2010, pp. 466-484.

[16]R. Ladhari and N. Suridan, "Determinants of loyality and recommendations: the role of perceived service quality emotional satistaction and image," Journal of Finansial Services Marketing, vol. 16, 2011, pp. 111-124.

[17]A. Pervaiz and S. Sudha, Online shopping - customer satisfaction and loyalty in Norway: Master's thesis. Blekinge Techniska Hogskola, 2007.

[18]J. Swan and L. Combs, "Product Performance and Customer Satisfaction: A New Conception," Journal of Marketing, vol. 40(2), 1976, pp. 25-33.

[19]B. Lewis, "Measuring Comsumer Expectation and Satisfaction," Customer Satisfaction research, 1995, pp. 57-76.

[20] C. Homburg and B. Rudolph, "Customer Satisfaction in Industrial Market: Dimentional and Multi Role Issues," Journal of Business Research, vol. 52(1), 2001, pp. 15-33.

[21]R. Brandt, "How Service Marketers Care identify Value Enhancing Service Elements," Journal of Services Marketing, vol. 2(3), 1988, pp. 35-41.

[22]E. Cadotte and N. Turgeon, "Dissatisfiers and Satisfiers: Sugestions from Customer Complaints and Compliments," Journal of Consumer Satisfaction Dissatisfaction and Complaining Behavior, vol. 1, 1988, pp. 74-79.

[23] S. Kristapsone, Zinātniskā pētniecība studiju procesā. Rīga: SIA „Biznesa augstskola Turība”, 2014.

[24]E. Vasermanis, D. Šķiltere and J. Krasts, Prognozēšanas metodes. Rīga: Latvijas Universitāte, 2002.

[25] S. Kristapsone and D. Kamerāde, Ievads pētniecībā: stratēgijas, dizaini, metode. Rīga: RaKa, Rīga, 2011. 